\title{
BioéthiqueOnline
}

\section{But the Pain Remains: A Response to Verpaelst}

\section{Marie-Hélène Raymond}

Volume 4, 2015

Reçu : 12 Jun 2015; publié : 29 Jun 2015; éditrices : Maude Laliberté \& Aliya Affdal; travail créatif discuté : F Verpaelst. A Pain in My Neck. BioéthiqueOnline 2015, 4/10

URI : https://id.erudit.org/iderudit/1035503ar

DOI : https://doi.org/10.7202/1035503ar

Aller au sommaire du numéro

Éditeur(s)

BioéthiqueOnline

ISSN

1923-2799 (numérique)

Découvrir la revue

Citer cet article

Raymond, M.-H. (2015). But the Pain Remains: A Response to Verpaelst BioéthiqueOnline, 4. https://doi.org/10.7202/1035503ar
Résumé de l'article

Les personnes aux prises avec la douleur chronique évitent parfois d'exprimer leur douleur ouvertement, par crainte d'être stigmatisées. Les professionnels de la santé travaillant auprès de cette clientèle peuvent également avoir de la difficulté à accepter la nature persistante de la douleur de leurs clients. À travers sa peinture, Verpaelst aide à surmonter ces difficultés. 


\title{
But the Pain Remains: A Response to Verpaelst
}

\author{
COMMENTAIRE / COMMENTARY \\ Marie-Hélène Raymond ${ }^{1}$
}

Reçu/Received: 12 Jun 2015

Éditrices/Editors: Maude Laliberté \& Aliya Affdal

Publié/Published: 29 Jun 2015

Travail créatif discuté/Creative Work discussed: F Verpaelst. A Pain in My Neck. BioéthiqueOnline 2015, 4/10

2015 M-H Raymond, Creative Commons Attribution 4.0 International License

\section{Résumé}

Les personnes aux prises avec la douleur chronique évitent parfois d'exprimer leur douleur ouvertement, par crainte d'être stigmatisées. Les professionnels de la santé travaillant auprès de cette clientèle peuvent également avoir de la difficulté à accepter la nature persistante de la douleur de leurs clients. À travers sa peinture, Verpaelst aide à surmonter ces difficultés.

\section{Mots clés}

douleur chronique, stigmatisation, gestion de la douleur, relations professionnels-patients, limites de la thérapie

\section{Summary}

People who experience chronic pain often refrain from expressing their pain overtly due to fear of stigmatization. Health professionals working with these persons may also find it challenging to face the persistent nature of their clients' pain. Through his painting, Verpaelst helps to overcome these difficulties.

\section{Keywords}

chronic pain, stigmatization, pain management, professional-patient relationship, limitations of therapy

Affiliations des auteurs / Author Affiliations

${ }^{1} \mathrm{OT}(\mathrm{c}), \mathrm{MSc}, \mathrm{PhD}$ candidate in Sciences de la réadaptation, Université de Montréal, Montréal, Canada

Correspondance / Correspondence

Marie-Hélène Raymond, marie.helene.raymond@umontreal.ca

Conflit d'intérêts

Conflicts of Interest

Aucun déclaré

None declared

\section{Preamble}

Over 15 years ago, I began my career as an occupational therapist in a multidisciplinary team with persons experiencing chronic pain. The goal of the program was to help our clients learn to continue living their lives and engaging in their activities despite the pain, and it seemed to me that the program was quite effective when the person shared that same goal. However, very often the client's goal was to reduce their pain, which was understandable but much less realistic. It was difficult for me to accept this fact and to face their disappointment, so after a few years I chose to redirect my career towards other clienteles. Most of my clinical work after that has been in home care with people experiencing loss of autonomy due to ageing or physical disabilities. Although the interpersonal aspect in this type of work has been much easier, I still find it difficult to accept the limitations of this service in terms of access (i.e., excessively long waiting lists). So in recent years, I also turned to research around questions of access to home care occupational therapy and waiting list prioritization.

When I saw Mr. Verpaelst's painting depicting his neck pain, I found it quite compelling. Like many people who spend too much time on the computer, I occasionally experience a few days with a pinched nerve in the neck, like the artist but to a lesser extent. And after writing this commentary, I am starting to wonder if repeatedly turning our head away from our professional limitations might also contribute to pinched nerves in the neck! 


\section{Commentary}

In a recent contribution to BioéthiqueOnline, Mr. Frank Verpaelst had the courage to share a visual expression of his chronic pain experience in the form of a watercolour painting entitled "A Pain in My Neck" [1]. This slightly abstract painting vibrantly represents the allencompassing, excruciating nature of the pain that tears through the artist's neck and whole upper body during his recurring bouts of pain. Of note, the pain itself, in red, seems to come alive at the forefront of the artist's self-representation, whereas the person in the background, in blue, is progressively erased, to the point of having no boundaries between him and the rest of the world on one side of his face.

In the text accompanying the painting, the artist explains why he usually tries to bury his pain, keeping it hidden from others. First of all, he knows that nothing can be done about it and sees no point in letting the pain take over his life. Second, he also has dwarfism and does not want to attract any further attention to his differences or disabilities. Concealing such suffering for days on end most likely takes up an unimaginable amount of energy. Yet, people with chronic pain have even more reasons to refrain from openly expressing their pain to others. They often experience stigmatization from society, healthcare professionals, and even their loved ones [2,3]. Because their condition is invisible and because the medical cause of pain is not always clear, they often fear, sometimes rightfully so, that others do not believe their pain or do not acknowledge its extent. They may also feel blamed for their pain, or get the impression that they are considered lazy when their pain interferes with their daily activities. "A Pain in My Neck" is all the more courageous as it overcomes all these barriers to the expression of pain in a powerful, authentic yet uncomplaining way.

From a different perspective, as a rehabilitation professional having worked in a multidisciplinary team with persons experiencing chronic pain, I cannot help seeing in Mr. Verpaelst's painting a vivid reminder of how ineffective we healthcare professionals can be in treating chronic pain. In fact, it is common for healthcare providers to experience feelings of frustration, guilt and powerlessness when working with chronic pain patients, because treatments are often unsuccessful at reducing pain, which can lead to tense patient-provider relationships [4]. In that sense, this painting can evoke strong emotions for healthcare professionals and it is almost tempting to turn our head away from it, leaving the pain in its safe, non-threatening, invisible place. But of course, that would serve no purpose.

Mr. Verpaelst seems to make no request in terms of medical intervention or rehabilitation for his pain. In any case, he seems to have already mastered many of the difficult lessons taught in multidisciplinary pain teams: minimizing overt pain behaviour and drug use, refusing to let the pain stop him from enjoying life... He has even found in "pain-ting" a meditative leisure activity that helps to "shift [his] consciousness away from [his] body, and into a happier headspace".

But despite all that, the pain remains.

Mr. Verpaelst, I so wish we could help you. In the meantime, I can only congratulate you for your "pain management behaviours" and encourage you to continue in your journey to greet your body's ups and downs with wisdom and introspection. Thank you for sharing your experience with such candidness and for reminding us to look beyond the surface... without turning our head away. 


\section{List of References}

1. Verpaelst F. (2015) A Pain in My Neck. BioéthiqueOnline, 4/10

2. Hansson K.S., Fridlund B., Brunt D., Hansson B., \& Rask M. (2011) The Meaning of the Experiences of Persons with Chronic Pain in their Encounters with the Health Service. Scandinavian Journal of Caring Sciences, 25(3), 444-450.

3. Monsivais, D.B. (2013) Decreasing the Stigma Burden of Chronic Pain. Journal of the American Association of Nurse Practitioners, 25(10), 551-556.

4. Matthias M.S., Parpart A.L., Nyland K.A., Huffman M.A., Stubbs D.L., Sargent C., \& Bair M.J. (2010) The Patient-Provider Relationship in Chronic Pain Care: Providers' Perspectives. Pain Medicine 11(1), 1688-1697. 